\title{
Leafroll disease is spreading rapidly in a Napa Valley vineyard
}

\author{
by Deborah A. Golino, Ed Weber, Susan Sim \\ and Adib Rowhani
}

In the 1930s and 1940s, little was known about viruses, and information on plant diseases caused by viruses was just beginning to appear in the scientific literature. Problems with grapevines in California, first referred to as "red leaf," were initially attributed to inexperience in viticultural techniques and poor growing conditions. However, the problem was later identified as leafroll disease, which causes red leaves, and poor yields and fruit quality. We evaluated its rate of spread for 5 years in a Napa Valley vineyard, and found an average rate of more than $10 \%$ per year. Leafroll disease can be vectored by low-level populations of grape mealybugs, and is now spreading rapidly in at least one Napa Valley vineyard for unknown reasons. Using stock for planting vines that is certified as virusfree is a key strategy in preventing the spread of grapevine leafroll disease.

$A$ California's wine industry de$1-$ veloped and grapevine plant-
ings expanded during the 1940s, new knowledge and methods of disease detection gradually made clear to scientists just how widespread virus disease problems were in the state's vineyards. A classic case involved leafroll disease in a red table-grape variety from Iran. Called 'Emperor', this variety was reported to be the third-most-important table grape in California in 1941. Often, growers reported low color development and sugar levels, which led to the idea that two varieties actually existed: the normal, red 'Emperor' and the so-called 'White Emperor'. However, in 1943, UC Davis viticulturist Harold Olmo and his colleagues determined that this problem was perpetuated by

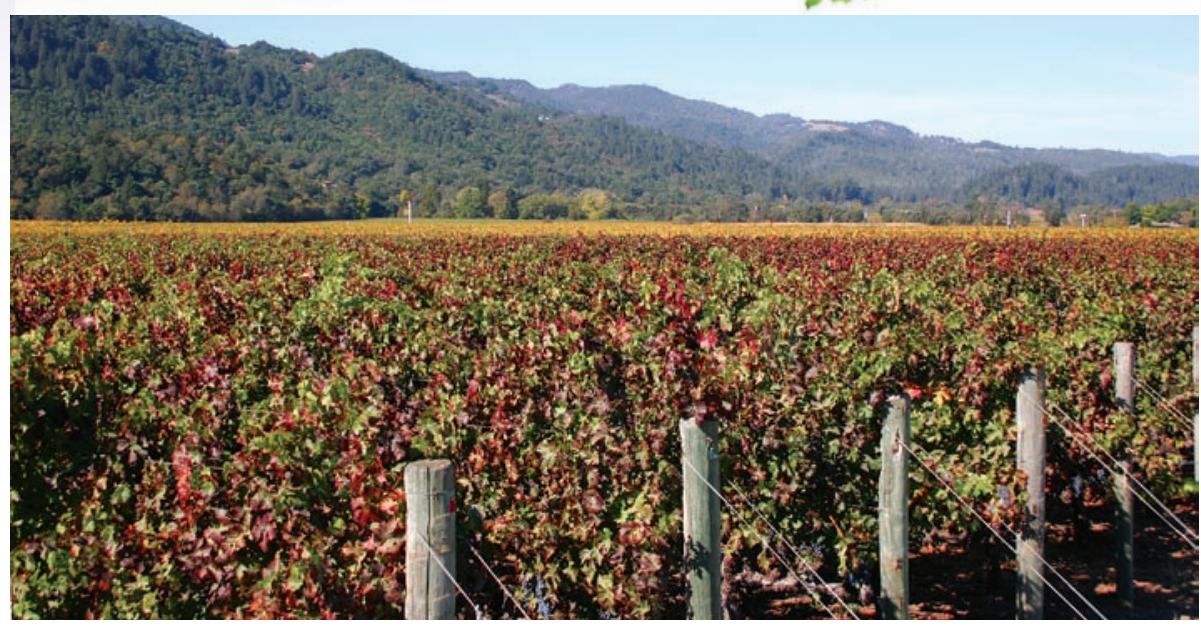

Grapevine leafroll, a viral disease that reduces fruit quality and yield, is diagnosed by the presence of red leaves (shown). The manager of this vineyard had observed low levels of grape mealybug, an effective disease vector, since the early 1990s.

vegetative propagation and proposed that a virus was involved (Olmo and Rizzi 1943).

In 1946, U.S. Department of Agriculture scientists in Fresno demonstrated that the 'White Emperor' condition was also transmissible via grafts, a method still considered to provide strong evidence that a virus is the causal organism (Alley and Golino 2000; Harmon and Snyder 1946). Grafting a piece of a diseased, infected plant onto a healthy plant can transmit a plant disease caused by a virus. Viruses move from one living cell to another (they are obligate parasites) and will move readily from the grafted piece of the diseased plant into the healthy plant to which it is grafted. This was an important piece of research in grapevine virology because it also linked virus disease with poor vineyard performance. The importance of propagation from healthy stock also became clear to researchers and industry (Alley and Golino 2000).

Significant progress was made in the 1960s and 1970s to reduce the incidence of leafroll disease in California vineyards. The grapevine certification program first proposed by Olmo in 1951 had become a reality, and the material produced in the program became widely available. This successful approach is based on the use of disease-tested grapevine nursery stock, produced at Foundation Plant
Services (FPS) at UC Davis through the California Grapevine Registration and Certification Program, which is overseen by the California Department of Food and Agriculture (Olmo 1951; Alley and Golino 2000). Through this program, virus-contaminated stock in commercial propagation is replaced with grape scion and rootstock varieties that are disease-tested, professionally identified and made available to grape growers by participating grapevine nurseries. The program is still active today.

However, many California grape growers continue to use noncertified planting stock, which is often infected with virus. Historically, where the absence of soil-inhabiting pests such as phylloxera or nematodes makes it possible, growers of wine, table and raisin grapes have planted vines that are simple rooted cuttings with no rootstock (known as rootings). Most often obtained from local vineyards, the propagating wood may be heavily infected with viruses. This can save money at planting time but inevitably costs growers money in the long term in reduced yields and quality of fruit. In areas where the insect phylloxera will kill vines unless resistant rootstocks are used, wine-grape growers often buy certified rootstock (free of virus) that is field-budded with scion wood (the fruitproducing top portion of the vine) obtained either locally or from a vineyard with a reputation for producing excellent 
wines. Much of this scion wood is infected with virus, and even though the certified rootstock is free of virus, the infected scion bud can transmit virus to the entire vine, from top to bottom.

Unfortunately, the use of propagating wood that is not checked for virus (also known as "common stock") has resulted in virus disease problems, ranging from mild to severe, in many California vineyards. Growers continue these practices, despite convincing evidence that modern vineyards do not perform optimally when a virus is present (D. Golino, in preparation). Furthermore, virus-borne diseases can result in significant losses of yield and fruit quality and may also lead to the death of vines (Martelli 2000). More than 50 different viruses are known to infect grapevines worldwide. The most common, economically damaging viruses in California are grapevine fanleaf virus, the grapevine leafroll viruses and the grapevine vitiviruses.

\section{Virus epidemiology}

In 1992, enzyme-linked immunosorbent assay (ELISA) tests were put into use at FPS for grapevine leafroll viruses. ELISA is a simple laboratory serological test that can in some cases substitute for field tests taking up to 2 years. (Weber et al. 2002) These tests revealed the presence of "grapevine leafroll associated viruses" (GLRaV) in previously healthy vines in a vineyard block from the 1960s maintained by FPS, indicating active virus spread in recent years (Rowhani and Golino 1995). FPS responded by removing the block from the Grapevine Registration and Certification program, increasing isolation distances from any grapevines that might have virus, and implementing a comprehensive virus-screening program with the new methodology. Since that time, new and increasingly sensitive laboratory tests for grapevine viruses have allowed regular testing of all FPS vines.

The critical remaining problem once these actions were taken was the lack of information on leafroll virus epidemiology. All the previous work had indicated that vine-to-vine spread of leafroll rarely occurred in California vineyards, and no insect vectors had been reported (Goheen 1989). However, when the distribution of infected plants in the old FPS vineyard was mapped, newly infected vines were frequently adjacent to those known to be diseased. Also, contrary to common wisdom at the time, this field spread appeared to have occurred fairly rapidly in just a few years (Rowhani and Golino 1995).

Taking our lead from work done in Europe and New Zealand, which demonstrated that mealybugs could spread leafroll viruses (Martelli 2000), we attempted to transmit California strains of leafroll virus with mealybug species found in California vineyards. At that time, we determined that four species of mealybug were able to transmit GLRaV-3 under experimental conditions. All four are commonly found in California vineyards: the obscure mealybug, Pseudococcus viburni (Signoret); the longtailed mealybug, Pseudococcus longi-spinus (Targioni Tozzetti); the citrus mealybug, Planococcus citri (Risso); and the grape mealybug, Pseudococcus maritimus (Ehrhorn) (Golino et al. 2002).

This work, along with the evidence of spread in the FPS vineyard, raised concerns among nurseries and growers about field spread of leafroll disease in California vineyards.

\section{Leafroll in a Napa vineyard}

In fall 2002, a viticulture researcher in Napa called to our attention a 12-year-old Cabernet Sauvignon vineyard in which leafroll disease appeared to be spreading. No leafroll disease had been evident in the early years after the block was planted in 1998, and the vines had been propagated with certified rootstock and field-budded with

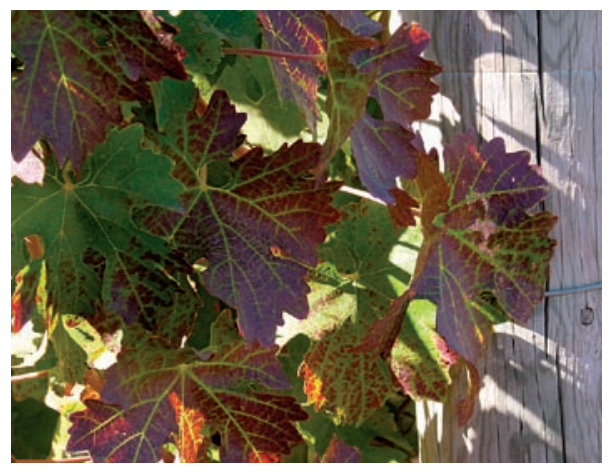

Symptoms of grapevine leafroll disease include red, cupped leaves. Older leaves are the first to show symptoms each summer, and symptoms are strongest just before leaf-fall. scion wood from a nonsymptomatic vineyard source. At this time, it was unusual for a Napa Valley grape vineyard to be propagated with certified scion wood, but management had made careful observations used to source the scion wood and it appeared to be free of symptoms. By 2002, however, many vines were showing characteristic symptoms of leafroll disease, including dark-red, cupped leaves with green veins and fruit that matures more slowly than on healthy vines. The majority of symptomatic vines were on one edge of the vineyard, close to an older vineyard that had leafroll disease.

Mapping leafroll. That fall, we began mapping disease incidence in a portion of the newly infected vineyard in an effort to determine the rate of spread of leafroll disease. Mapping continued until fall 2006 (fig. 1). The mapped vineyard (block 1) was 'Cabernet Sauvignon' planted in 1989 on several different rootstocks with 6 feet (about 2 meters) between rows and 3.3 feet ( 1 meter) between vines in the row. The block was budded on several different rootstocks because the winery was beginning to replace blocks planted with AXR-1 with alternative rootstocks. The source of the budwood is uncertain, but no leafroll symptoms were observed for the first 9 or 10 years, suggesting that the original stock was free of virus. Redleaf symptoms of leafroll appeared in this vineyard in 2000, primarily at the eastern ends of the rows. The number of symptomatic vines was reported to be increasing each year.

Across an avenue from the eastern end of this block was another Cabernet Sauvignon vineyard (block 2) that was

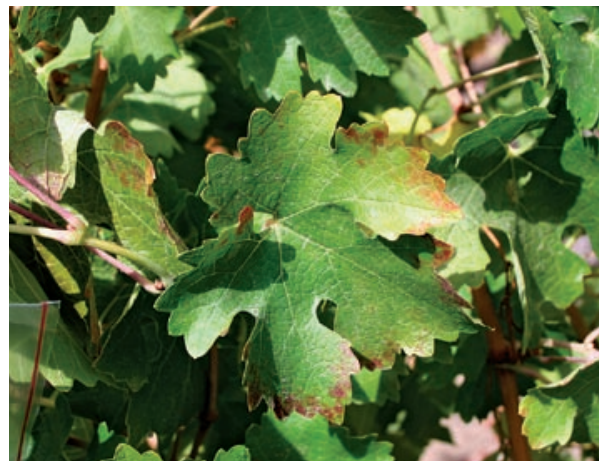

Leafroll symptoms in some vines were mild and showed reddening only at the leaf margin on a few leaves; this plant tested positive using ELISA for GLRaV-3. 


\section{Each year, a larger proportion of the vineyard was diseased, reducing yield and quality with each increment of spread.}

planted from 1970 to 1972 (fig. 1). This planting was heavily infested with leafroll, as evidenced by the red-leaf symptoms throughout the block reported by the vineyard manager. This vineyard was pulled in 1994 due to leafroll disease and the field was replanted in 1998 after a 4-year fallow. Grape mealybugs were observed in both these blocks most years, but never reached population levels where insecticide treatments were made.

In October 2002, we mapped part of the newly infected block 1 to assess the incidence and pattern of vines with leafroll symptoms. The mapped area included 98 complete rows (approximately 15,680 vines) and covered 7.2 acres (fig. 1, orange section of block 1 ). When infected with leafroll virus, Cabernet Sauvignon normally produces strong, characteristic visual symptoms that most notably include dark-red cupped leaves with green veins. Vines were individually rated for symptoms of leafroll disease using a scoring system of: $0=$ no symptoms; $1=$ mild or severe symptoms; $\mathrm{Q}=$ questionable (usually difficult to determine due to mite feeding on leaves, which can also cause leaf-reddening); $\mathrm{C}=$ canker symptoms masking possible leafroll symptoms; and $\mathrm{X}=$ dead or missing vine. Observations were made annually from October 2002 through October 2006.

ELISA testing. To test the accuracy of the 2002 visual-symptom ratings in block 1, 75 petiole samples were tested using ELISA for four grapevine leafroll associated viruses: GLRaV-1, GLRaV-2, GLRaV-3 and GLRaV-4 (Weber et al. 2002). Using our symptom scoring system, 35 of these samples were from vines rated strongly positive for leafroll, 20 vines rated negative and 20 vines rated questionable.

The ELISA testing found only GLRaV-3 in samples from symptomatic vines. The visual-symptom ratings were very accurate, although not in perfect agreement with the ELISA testing. All 35 samples from vines visually rated as positive for leafroll were also positive for GLRaV-3 by ELISA testing. In addition, all of the vines rated as questionable tested negative for virus. However, 2 of the 20 vines $(10 \%)$ rated negative actually tested positive for GLRaV-3. It is possible that these two positive
ELISA tests were examples of vines that were already infected but not yet showing symptoms. Nonetheless, it was clear that visual symptoms were highly correlated with the presence of virus and could be used for large-scale mapping.

With this background information, in subsequent years we eliminated the "questionable" and "canker" categories from the rating system, so that each plant was rated either negative for leafroll, positive for leafroll, dead or missing.

In fall 2007, we repeated ELISA testing on 204 vines to access the accuracy of our visual ratings. Out of 101 vines visually rated as positive for leafroll disease, all but one tested using ELISA were positive for GLRaV-3. Out of 103 vines visually rated as negative, all but three also tested using ELISA were negative for GLRaV-3. It is highly probable that the three latter nonsymptomatic vines represented early stages of infection when there were mild or no symptoms. In our experience, mild symptoms are easily overlooked.

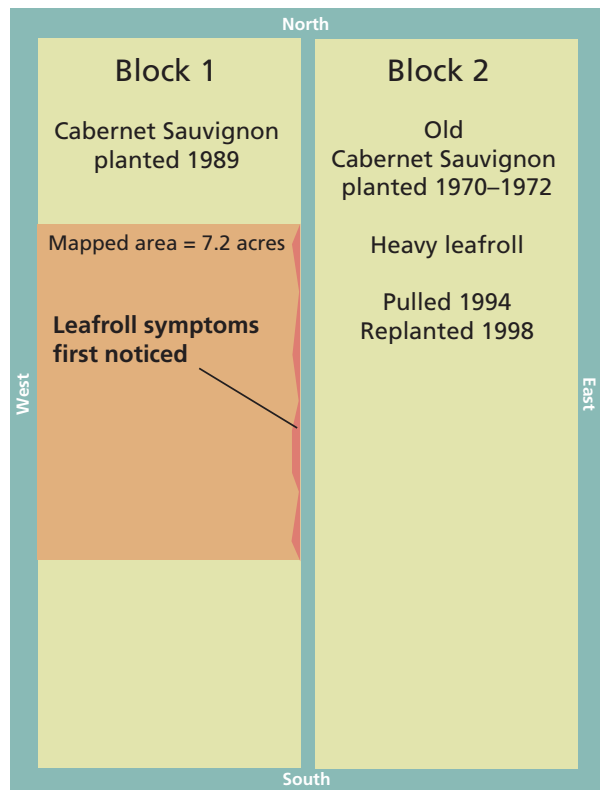

Fig. 1. Leafroll spread was mapped in a Napa Valley Cabernet Sauvignon vineyard planted in 1989 , west of an older block heavily infected with leafroll. The two blocks were side by side for 5 years, providing the opportunity for leafroll disease to move from the old block to the new. The red section shows where leafroll symptoms were first noticed. Mapping was conducted each fall from 2002 to 2006 on a vine-by-vine basis in the 7.2 acres indicated by the orange area.

\section{Quantifying virus spread}

Our 2002 mapping results showed that leafroll symptoms were present in $23.3 \%$ of the vines in the mapped area of block 1 (fig. 2). The distribution of symptomatic vines suggested that leafroll initially spread from block 2 (the adjacent, older, infested block) into the eastern end of block 1 , and subsequently spread down the rows toward the west. Nearly all vines on the eastern ends of the rows were rated positive for leafroll, and only a handful were positive on the western end.

The incidence of symptomatic vines in the mapped area increased to $41.2 \%$ in 2003 and to $45.8 \%$ in 2004, and the distribution of diseased vines continued to show evidence of spread from east to west. We also observed leafroll symptoms in the more recently planted vines in block 2, suggesting that leafroll had now spread back into the new vines in block 2 from the diseased vines in block 1 .

In 2004, there was such a difference in fruit quality and ripening patterns that the vineyard was harvested twice - as two separate fruit loads with different harvest dates. Fruit from the healthy vines ripened earlier, was better quality and was used for reserve wines, which command a higher price. Fruit from the diseased vines was picked several weeks later and was not used for reserve wines.

The incidence of leafroll kept increasing, reaching $49.8 \%$ in 2005 and $66.1 \%$ at the end of our study in 2006 (fig. 3). Due to the inferiority of fruit from the infected vines, the vineyard owner is now faced with the need to replant this block after only 15 years. Most grape growers would expect a much longer vineyard life for their initial investment, quite often twice this long. In 2003, UC cost studies estimated the cost of establishing an acre of vineyard in the North Coast at about $\$ 25,000$; no harvest would be expected in the first 3 years while the vineyard is being established. It is easy to see that more-rapid replanting of vines due to leafroll spread in vineyards could greatly increase the cost of grape-growing in any part of California affected by this problem.

\section{Role of grape mealybug}

The vineyard manager, who is an entomologist, had observed grape 


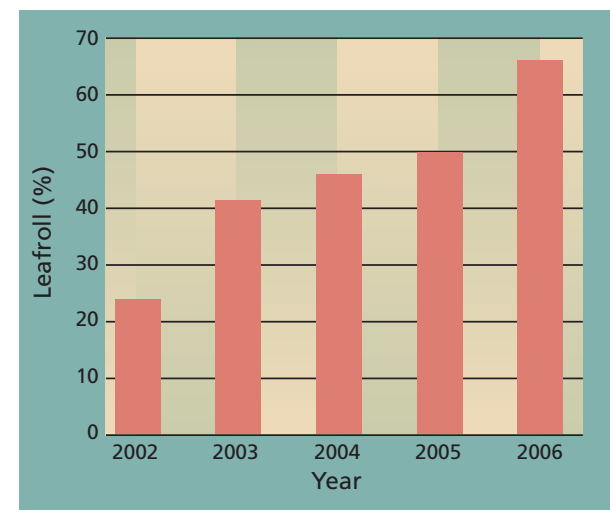

Fig. 2. From 2002 to 2006, the percentage of leafroll-symptomatic vines in a Napa County Cabernet Sauvignon vineyard increased from $23.3 \%$ to $66.1 \%$, an increase of more than $10 \%$ per year.

mealybug in this and surrounding vineyards over many years. The mealybugs were at low populations that were not considered problematic because they did not cause obvious economic damage. However, a low population can still serve as an effective vector for virus diseases in many crop systems without doing direct, significant damage to the plants. Therefore, we believe that the mealybugs were likely responsible for transmitting GLRaV-3 between blocks 1 and 2, and for the spread documented in block 1 . The risk of leafroll spread from such small populations had not previously been a consideration when potential damage from grape mealybug was assessed. Similar low populations of grape mealybug are regularly observed in much of Napa Valley (Kent Daane, personal communication).

The steady increase in infection rate seen in our mapping study is the first documentation of significant and rapid field spread of leafroll disease in a California vineyard. The significance of this spread to the grower is clear: each year, a larger proportion of the vineyard was diseased, reducing yield and quality with each increment of spread (figs. 2 and 3).

\section{Possible causes for rapid spread}

Several other vineyards in California have been reported recently by growers at meetings to exhibit leafroll spread at rates similar to those documented here. We believe that if such high rates of leafroll spread had occurred in the past in California, the problem would have been described by a number of excellent researchers who have worked on grape-

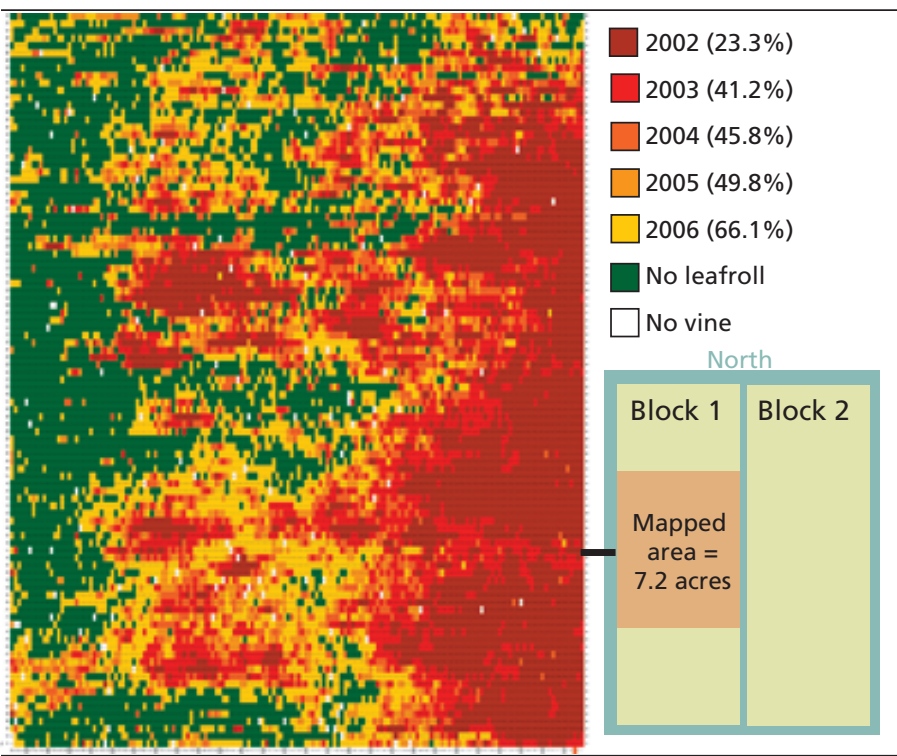

Fig. 3. Spread of grapevine leafroll virus in the mapped area of block 1 (see fig. 1) of a Napa County Cabernet Sauvignon vineyard, 2002-2006.

vine virus diseases or by observant vineyard managers. That they never did so suggests that something fundamental has changed in these vineyards to allow such spread to occur, such as vector epidemiology, grower rootstock preferences and/or new leafroll strains that are more easily transmitted in California vineyards.

Vector epidemiology. While the possibility always must be considered, nothing has been observed to suggest that a new vector is responsible for the spread of grapevine leafroll disease observed in this study. The vineyard had a history of grape mealybug, which has been in California throughout its grape-growing history. In addition, while the vine mealybug is blamed for rapid spread of leafroll disease in South Africa (Martelli 2000), it was only recently introduced to California and is not yet present in Napa Valley. In the late 1980s, vine mealybug was the first species of this pest reported in the international literature to transmit leafroll virus (Martelli 2000).

Unfortunately, we expect vine mealybug to be an effective vector of leafroll virus in California. First discovered in the Coachella Valley in the late 1990s, the vine mealybug has slowly spread north throughout the state (Daane et al. 2006). This serious pest is difficult to control, and control is even more critical because the insect is known to be a vector of leafroll viruses. Thus if vine mealybug becomes established throughout California, leafroll could spread even more aggressively (see pages 167 and 174). We do not, however, believe it caused the leafroll disease spread that we saw in the study vineyard.
The population dynamics of the vector could also have been affected by changing pest-management practices in the vineyard, and possibly linked to changes in the number of parasites and predators of the leafroll virus vector. Detailed monitoring of many species of arthropods that inhabit vineyards would be needed to determine whether this played a role in leafroll spread.

Rootstock preferences. Today's California rootstocks are less tolerant of leafroll infection than own-rooted vines or vines grafted on the rootstock AXR-1, which was used by the majority of grape growers until it succumbed to an epidemic of type B phylloxera in the early 1980s. AXR-1 rootstock (also known as Ganzin 1) is a cross between the variety 'Aramon' and Vitis rupestris; it is generally believed that the Vitis vinifera in 'Aramon' led to its failure. (Golino 1993; Golino et al. 2003). The previous generation of Napa Valley vineyards was planted primarily on AXR-1, which is much more tolerant of leafroll infections than many rootstocks currently in use (D. Golino, in preparation). A vine propagated on AXR-1 rootstock and infected with leafroll disease can show mild or little symptoms. Today, 10 to 15 different rootstocks are commonly in use and many of them are extremely sensitive to viruses.

Perhaps leafroll viruses have always spread among vines in our vineyards, but the symptoms simply were not evident in most cases because the rootstocks were more disease-tolerant and showed fewer symptoms. This could account for at least part of the apparent change in epidemiology. Given the greater susceptibility of today's root- 
stocks, choosing both rootstocks and scion wood free from leafroll infection is far more critical than in the past.

New leafroll virus strains. At this writing, there are at least 10 different species of leafroll virus, each in a taxonomically distinct group. Most have the genetic fingerprint of a group of viruses known to be transmitted by mealybugs. In fall 2006, we tested for all these leafroll species in our study vineyard, but only GLRaV-3 was found, and this species is known to be mealybug-transmitted. All

\section{In memory of Ed Weber}

Ed Weber, a coauthor of this article, was a longtime Napa County Cooperative Extension Advisor. He knew Napa vineyards well and was among the first viticulturists to observe an apparent increase in

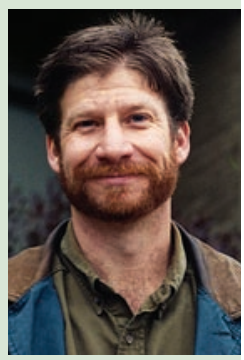
the grapevine leafroll infection rate. Weber died unexpectedly on Dec. 31, 2007 , at the age of 51 . This article is dedicated to him.

Weber attended UC Davis, where he earned a B.S. in plant sciences and an M.S. in horticulture, with an emphasis on viticulture. He worked as viticulturist for Joseph Phelps Vineyards from 1983 until 1988, when he joined UC Cooperative Extension in Napa County. Weber served as a liaison between the University and its researchers, winemakers, and state and local regulatory agencies.

In the wine industry, Weber was known as a great educator, communicator and problem-solver. His exceptional talent for speaking and writing was accompanied by an ability to take complicated data and information and convey it in a straightforward and logical way that could be understood by industry professionals as well as the general public.

In addition to his research and expertise in viticulture, Weber provided administrative leadership as Napa County Director and served as chair of the ANR Communications Advisory Board. of the vines that became symptomatic of leafroll disease and were tested had this type of leafroll. We believe some strains of GLRaV-3 were present in California when grapevines were first introduced - it is often found in our oldest vineyards, even in isolated locations. However, plant viruses are highly mutable and within-species severity may vary greatly. Is it possible that a strain of GLRaV-3 was inadvertently introduced with grape cuttings smuggled into California from Europe or elsewhere? With the number of illegal importations known to have occurred in the past 20 years, this is a distinct possibility.

\section{Research needs}

Additional research is urgently needed to help us better understand our observation of rapid spread of leafroll disease in the vineyard. Related ongoing UC projects include work on the transmission biology of leafroll viruses by mealybugs, mealybug management and the impacts of 10 known species of leafroll viruses on grape scions and rootstocks. At this time, specific recommendations for mealybug controls to prevent virus spread are still under development. If leafroll virus spread also occurs across other grape-growing regions of California, as has been observed in this study of a Napa Valley vineyard, the disease will have a far greater impact than ever on vineyard productivity. Therefore, breeding programs should also be initiated to de- velop resistance in both scion varieties and rootstocks using traditional breeding strategies and possibly molecular biology techniques. This would be the ultimate sustainable approach to controlling this disease.

In the meantime, grape growers are strongly advised to plant their vineyards using only certified planting material that has been screened for virus. Where that is not possible due to winemaker preferences or other factors, propagating stock should be carefully screened for virus using laboratory tests (Weber et al. 2002), and only the healthiest possible stock should be used for propagation. Maximizing the distance between new plantings and virus-infected old plantings should reduce the rate of spread. Care should be taken to ensure that equipment, personnel and pomace moving between vineyards (see page 172) are not contaminated with mealybugs that might be carrying leafroll virus.

D. Golino is Cooperative Extension Plant Pathology Specialist, Department of Plant Pathology, UC Davis; E. Weber was County Director and Farm Advisor, UC Cooperative Extension Napa County (deceased; see box); and S. Sim is Staff Research Associate, and A. Rowhani is Plant Pathology Specialist, Department of Plant Pathology, UC Davis. This project was initiated with funding from the American Vineyard Foundation and the California Competitive Grant Program for Research in Viticulture and Enology. We acknowledge the invaluable help of Joshua Chase, Justin Jacobs, Judy Lee, Laurel Leon and Yvonne Rasmussen in the survey work and laboratory testing.

\section{References}

Alley L, Golino D. 2000. The origins of the grape program at Foundation Plant Materials Service. Proc 50th Annual ASEV Meeting. Seattle, WA. Am J Enol Vitic 51:222-30.

Daane K, Bentley W, Walton V, et al. 2006. New controls investigated for vine mealybug. Cal Ag 60:31-8.

Goheen AC. 1989. Virus diseases and grapevine selection. Am J Enol Vitic 40:67-72

Golino D. 1993. Potential interactions between rootstocks and grapevine latent viruses. Am J Enol Vitic 44:148-52.

Golino DA, Sim ST, Gill R, Rowhani A. 2002. Grapevine leafroll disease can be spread by California mealybugs. Cal Ag 56(6):196-201

Golino DA, Sim ST, Rowhani A. 2003. The role of rootstock genotype in the effects of single and mixed infections of grapevine viruses. Proc 14th Int Council for the Study of Virus and Virus-like Diseases of Grapevine (ICVG) Conference. Bari, Italy. p 246-7.
Harmon FN, Snyder E. 1946. Investigations on the occurrence, transmission, spread, and effect of "white" fruit color in the Emperor grape. Proc Am Soc Hort Sci 47:190-4.

Martelli GP. 2000. Major graft-transmissible diseases 50 th Ann ASEV Meeting. Seattle, WA. Am J Enol Vitic 51:231-6.

Olmo HP. 1951. A proposed program for the introduction, improvement, and certification of healthy grape varieties. Wines Vines 32 (7):7-9.

Olmo HP, Rizzi AD. 1943. Selection for fruit color in the Emperor grape. Proc Am Soc Hort Sci 42:395400

Rowhani A, Golino D. 1995. ELISA test reveals new information about leafroll disease. Cal Ag 49(1):26-9.

Weber E, Golino DA, Rowhani A. 2002. Laboratory testing for grapevine virus diseases. Practical Winery Vineyard 22(2):13-26. of grapevines: Nature, diagnosis, and sanitation. Proc 